\title{
Small-mammal hunting by two ethnic groups in north-western Ecuador
}

\author{
E. Suárez, J. Stallings and L. Suárez
}

A small-mammal hunting study was carried out in north-western Ecuador from October 1992 to October 1993, employing interview and trapping methods to document rodent and marsupial hunting by Chachi Indian and Afroecuadorian families. Based on 109 family interviews in 28 communities, it was determined that log-fall traps were used around family gardens and along forest trails. Afroecuadorian families used more than twice the number of traps than Chachis and trap lines of both ethnic groups were left open for approximately 6 days per trapping session. Chachi families left trap lines closed twice as long as Afroecuadorian families. There were 857 individuals of seven rodent and four marsupial species trapped during the study, with Proechimys semispinosus representing more than 50 per cent of the small mammals trapped.

\section{Introduction}

Reports of Neotropical wildlife hunting have traditionally focused on sport hunting by nonindigenous hunters (for example, Dallmeier, 1991; Purdy and Tomlinson, 1991) or on subsistence hunting by ethnic groups (for example, Redford and Robinson, 1987; Mittermeier, 1991; Vickers, 1991). In the latter case, little attention has been devoted to the hunting of small mammals $(\leq 1.0 \mathrm{~kg})$ by ethnic groups. Although many ethnozoological studies have reported that small mammals are taken by ethnic groups (for example, Redford and Robinson, 1987), to our knowledge no studies have focused exclusively on the hunting efforts used to capture them.

In this paper we report on small-mammal hunting by Afroecuadorian and Chachi Indian families in north-western Ecuador. Larger game has been locally extirpated in this area (Albuja and Mena, 1987; Pearson, 1992; Cevallos, 1993) and local people spend considerable time and energy in constructing and using small-mammal traps (Albuja and Mena, 1987; Suárez, 1993).

Interview and trapping techniques were used to document small-mammal hunting by Chachis and Afroecuadorians and to evaluate the importance of this resource to these two groups.

\section{Study areas}

This study was carried out in the zone abutting the western portion of the CotacachiCayapas Ecological Reserve in 28 communities on the Santiago, Cayapas and Onzole Rivers (Figure 1). The communities studied were located at elevations ranging from 50 to $200 \mathrm{~m}$ above sea level and the vegetation is classified as Very Humid Tropical Forest (Cañadas, 1983).

Numerous Chachi and Afroecuadorian communities are situated along the three rivers and their smaller tributaries. Both ethnic groups are sedentary and can be found living side by side in the same communities or in separate ethnic communities. They have occupied the region for over 300 years and depend largely on products that they obtain from the forest, their gardens and the rivers. They use these for their own needs or sell surplus products (e.g. crops) and timber at local markets or commercial centres. 


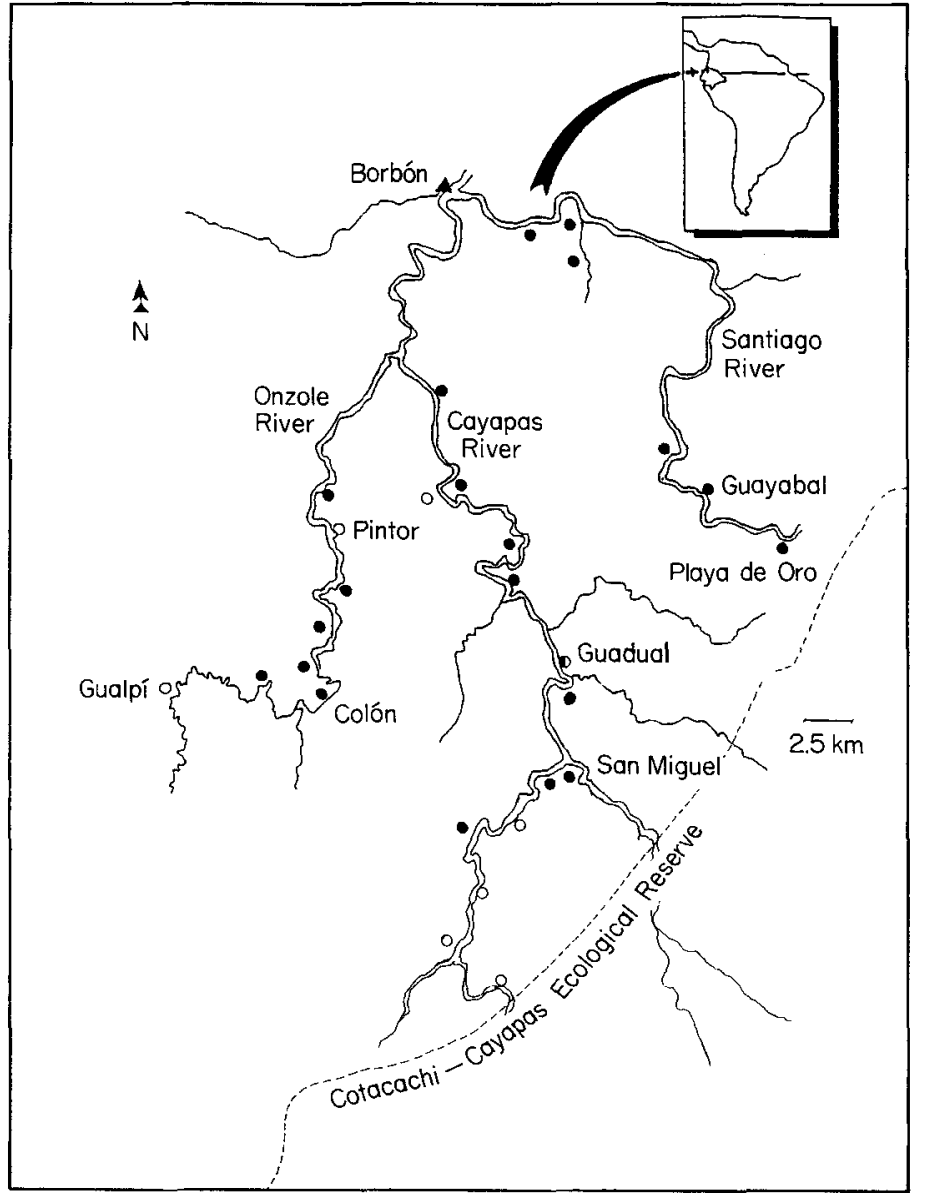

Figure 1. Map of the lower portion of CotacachiCayapas Ecological Reserve and its buffer zone in north-western Ecuador. Solid black circles and open circles represent Afroecuadorian and Chachi communities, respectively, where interviews and small-mammal trapping were conducted. The solid triangle pinpoints the location of Borbon.

\section{Methods}

Monthly visits were made to the study area from October 1992 to October 1993 to conduct standardized interviews with Chachi and Afroecuadorian families regarding smallmammal hunting. In each community visited, three or four families were selected at random and interviewed to discover:

- number and type of traps used and preferred setting location;

- number of days that traps are left set per trapping session;

- number of weeks that traps are closed and reason for closing them;

- types of baits used;

- which species are trapped frequently.

In addition to the interviews, visits were made with the trap-line owner to at least seven trap lines each month when traps were set and checked. During these visits the following information was recorded for each animal captured: local Spanish name; scientific name; sex; weight $(\mathrm{g})$; head, tail, body and hind foot lengths $(\mathrm{mm})$; general habitat type.

\section{Results}

We conducted 109 family interviews in 28 communities (Figure 1) on the Santiago, Cayapas and Onzole Rivers (Table 1). Most of the interviews were conducted on the Cayapas River (48.62 per cent), with 24 (22.01 per cent) and 32 (29.35 per cent) conducted on the Santiago and Onzole Rivers, respectively. 
Table 1. Ethnic communities where interviews were conducted regarding smallmammal hunting in northwestern Ecuador

\begin{tabular}{|c|c|c|c|}
\hline \multirow{2}{*}{$\begin{array}{l}\text { Community } \\
\text { La Herradura }\end{array}$} & \multirow{2}{*}{$\begin{array}{l}\text { Ethnic group } \\
\text { Afroecuadorian }\end{array}$} & \multicolumn{2}{|c|}{ No. interviews River } \\
\hline & & 4 & Cayapas \\
\hline Santa María & Afroecuadorian & 4 & Cayapas \\
\hline Telembí & Afroecuadorian & 4 & Cayapas \\
\hline Majua & Afroecuadorian & 4 & Cayapas \\
\hline San Miguel & Afroecuadorian & 4 & Cayapas \\
\hline Las Peñas & Afroecuadorian & 3 & Cayapas \\
\hline Virguela & Afroecuadorian & 4 & Cayapas \\
\hline \multirow[t]{2}{*}{ Zapallito } & Afroecuadorian/ & & \\
\hline & Chachi & 3 & Cayapas \\
\hline Zapallo Grande & Chachi & 3 & Cayapas \\
\hline Guadual & Chachi & 3 & Cayapas \\
\hline Tigrillo & Chachi & 4 & Cayapas \\
\hline La Tranca & Chachi & 4 & Cayapas \\
\hline Calle Mansa & Chachi & 4 & Cayapas \\
\hline Corriente Grande & Chachi & 5 & Cayapas \\
\hline Playa de Oro & Afroecuadorian & 4 & Santiago \\
\hline Guayabal & Afroecuadorian & 4 & Santiago \\
\hline Selva Alegre & Afroecuadorian & 4 & Santiago \\
\hline Maldonado & Afroecuadorian & 4 & Sartiago \\
\hline Colón Eloy & Afroecuadorian & 4 & Santiago \\
\hline Boca de María & Afroecuadorian & 4 & Santiago \\
\hline Agua Clara & Afroecuadorian & 4 & Onzole \\
\hline Colón & Afroecuadorian & 4 & Onzole \\
\hline Sto. Domingo & Afroecuadorian & 4 & Onzole \\
\hline Zancudo & Afroecuadorian & 4 & Onzole \\
\hline Arenales & Afroecuadorian & 4 & Onzole \\
\hline Boca del Cuandé & Afroecuadorian & 4 & Onzole \\
\hline Gualpí & Chachi & 4 & Onzole \\
\hline Pintor & Chachi & 4 & Onzole \\
\hline Total & & 109 & \\
\hline
\end{tabular}

The majority (69 per cent) were conducted with Afroecuadorian families, reflecting the population dominance of this ethnic group in the region.

The results of the interviews (Table 2) revealed that Afroecuadorian families use more traps in their trapping configurations than
Chachi families and that Chachi families leave their traps closed for longer periods of time. There were no differences between ethnic groups in the number of days that traps were left open per trapping session.

Other significant tendencies were that the Chachi families did not have names in the

Table 2. Comparisons of small-mammal hunting systems by Chachi and Afroecuadorian families in northwestern Ecuador

\begin{tabular}{lll}
\hline & Chachi families & Afroecuadorian families \\
\hline No. traps/trap line & & \\
No. day trap lines open/session & $9.67( \pm 10.6)$ & $19.64( \pm 27.22)$ \\
No. weeks trap lines closed between sessions & $6.00( \pm 12.10)$ & $6.00( \pm 4.08)$ \\
Names used for trap parts & $11.46( \pm 47.7)$ & $5.7( \pm 11.11)$ \\
Maintained well-established trap lines & No & Yes \\
Used live and dead weight traps & No & Yes \\
Used large dead weight traps & No & Yes \\
Used various baits for dead weight traps & No & Yes \\
\hline
\end{tabular}




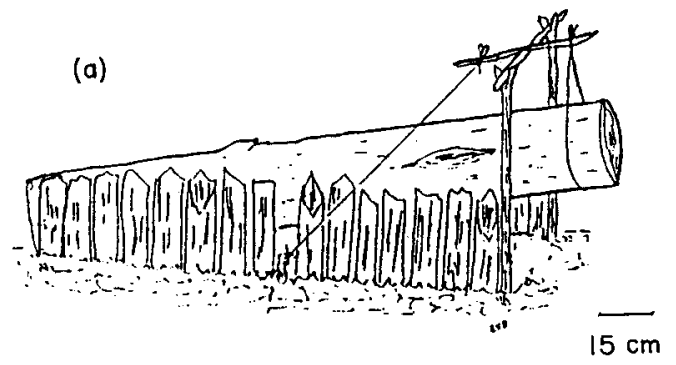

(c)

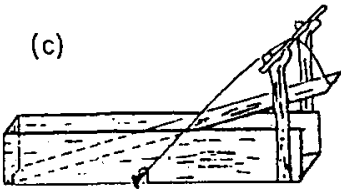

$6 \mathrm{~cm}$

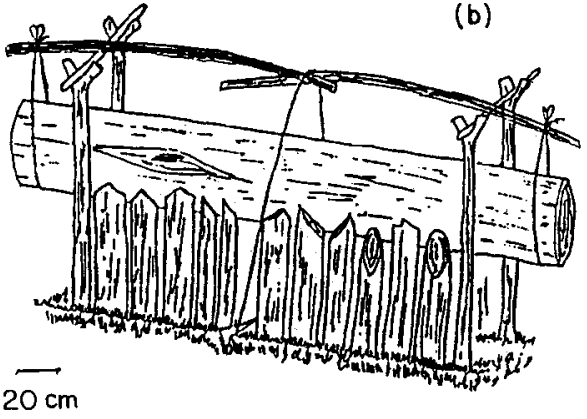

(d)

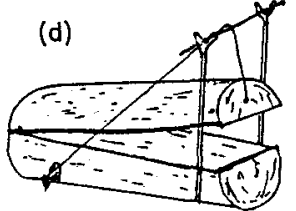

$\widetilde{6 m}$

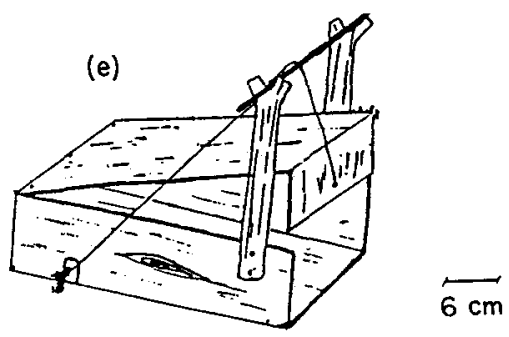

Figure 2. Trap types identified during the study in the buffer zone of Cotacachi-Cayapas Ecological Reserve: (a) small mammal log-fall trap; (b) large mammal log-fall trap; (c) trap for killing black rats Rattus rattus in the houses of Afroecuadorian families; (d) and (e) live traps for capturing birds and small mammals.

Table 3. Small mammal species and the local Spanish names, percentage of total captures and mean weight of individuals captured in log-fall traps during 65 days of trapping in north-western Ecuador

\begin{tabular}{lrrrl}
\hline Species & No. captures & \% total & Weight $(\mathrm{g})$ & Local name \\
\hline Proechimys semispinosus & 445 & 51.9 & 294.5 & Raton liso \\
Oryzomys caliginosus & 139 & 16.2 & 50.5 & Churi negro \\
Oryzomys alfaroi & 98 & 11.4 & 32.4 & Churi blanco \\
Didelphis marsupialis & 49 & 5.7 & 427.0 & Zorra hedionda \\
Marmosa robinsoni & 45 & 5.2 & 86.3 & Liron \\
Philander opossum & 25 & 2.9 & 327.0 & Cuatro oja \\
Hoplomys gymnurus & 20 & 2.4 & 379.3 & Raton pumuyo \\
Oryzomys sp. & 12 & 1.4 & 75.3 & Churi caniceto \\
Heteromys australis & 12 & 1.4 & 55.5 & Raton bolson \\
Tylomys mirae & 8 & 1.0 & 255.3 & Raton morro \\
Caluromys derbianus & 4 & 0.5 & 305.7 & Coquero \\
Totals & 857 & 100 & & \\
\hline
\end{tabular}


Chachi language for trap parts, nor did they recognize trap part names used by Afroecuadorians. Afroecuadorians used names for all trap parts and the names were identical across all three rivers. In addition, Chachi Indians generally (74 per cent) used banana tree trunks for the 'bum' or log, in contrast to wood used by Afroecuadorians ( 95 per cent). Over 47 per cent of Chachi Indians interviewed stated that they change trapping locations, while Afroecuadorians (97.5 per cent) tended to use the same trapping areas. More than 25 per cent of the Chachi hunters learned trapping methods from Afroecuadorians but all Afroecuadorians learned trapping methods from their families.

Five trap types were observed. Two types of live 'box' traps were identified; these were used exclusively by Afroecuadorian children (Figure 2). Three log-fall traps were identified: (i) for killing European black rats Rattus rattus in Afroecuadorian family homes; (ii) which Afroecuadorians used to kill larger mammals (e.g. Tayassu, Mazama, Dasyprocta and Agouti); and (iii) smaller traps used by Afroecuadorian and Chachi families for capturing small mammals around family gardens and along pre-established forest trails.

The majority (67.8 per cent) of the interviews showed that both ethnic groups preferred to establish their trap lines around family gardens rather than along forest trails.
Over 77 per cent of Chachis and 64 per cent of Afroecuadorians stated that they set their trap lines around gardens.

Afroecuadorian selection of baits for log-fall traps depended on the location of the trap lines. They used banana exclusively around family gardens, while along forest trails they selected forest fruits such as Wettinia utile, Bactris gasipaes, Phytelephas aequatorialis and Artocarpus altilis. Only 10 per cent of Chachi hunters selected baits for different habitats and the majority used only banana for $\log$-fall traps.

During the study 857 individuals of seven rodent and four marsupial species, from the families Didelphidae, Muridae, Echimyidae and Heteromyidae, were recorded from 1704 log-fall traps over a trapping period of 65 days (Table 3). Tomes's spiny rat Proechimys semispinosus was the species captured most frequently (445 individuals, 52 per cent of captures). The mean weight of all individuals of this species was $294.5 \mathrm{~g}$, with over half the captures being subadults.

More than twice the number of small mammals were captured around family gardens than along forest trails (Table 4). Proechimys semispinosus, Oryzomys caliginosus, Didelphis marsupialis, Marmosa robinsoni and Caluromys derbianus were more frequently captured around gardens, while Oryzomys alfaroi, Philander opossum, Hoplomys gymnurus,

Table 4. Number of small mammals captured (and respective percentage of total) in log-fall traps around family gardens and along forest trails by Chachi and Afroecuadorian families during a 65 -day sample in north-western Ecuador

\begin{tabular}{|c|c|c|c|c|c|}
\hline \multirow[t]{2}{*}{ Species } & \multicolumn{2}{|c|}{ Gardens } & \multicolumn{2}{|c|}{ Forest } & \multirow{2}{*}{$\begin{array}{l}\text { Local name } \\
\text { (Spanish) }\end{array}$} \\
\hline & No & $(\%)$ & No. & $(\%)$ & \\
\hline Proechimys semispinosus & 334 & (75) & 111 & $(25)$ & Raton liso \\
\hline Oryzomys caliginosus & 114 & (82) & 25 & (18) & Churi negro \\
\hline Oryzomys alfaroi & 45 & (46) & 53 & (54) & Churi blanco \\
\hline Didelphis marsupialis & 40 & $(82)$ & 9 & (18) & Zorra hedionda \\
\hline Marmosa robinsoni & 38 & (84) & 7 & (16) & Liron \\
\hline Philander opossum & 6 & (24) & 19 & $(76)$ & Cuatro oja \\
\hline Hoplomys gymnurus & 0 & & 20 & $(100)$ & Raton pumuyo \\
\hline Oryzomys sp. & 2 & (17) & 10 & $(83)$ & Churi caniceto \\
\hline Heteromys australis & 1 & $(8)$ & 11 & $(92)$ & Raton bolson \\
\hline Tylomys mirae & 0 & & 8 & $(100)$ & Raton morro \\
\hline Caluromys derbianus & 3 & (75) & 1 & (25) & Coquero \\
\hline Totals & 583 & (68) & 274 & (32) & \\
\hline
\end{tabular}


Oryzomys sp., Heteromys australis and Tylomys mirae were captured more frequently along forest trails.

Twenty trap lines were monitored from start to finish of a monthly trapping session. Trapping success per line ranged from 9.7 to 61 per cent, with an overall mean success of 24.3 per cent for the trapping session.

\section{Discussion}

The importance of small-mammal hunting by ethnic groups from the north-western Andes has been suggested previously, although very few data are available on number of species taken and hunting systems used. Albuja and Mena (1987) stated that Afroecuadorians and Chachi Indians in north-western Ecuador hunted small mammals using log-fall traps and that P. semispinosus and Hoplomys gymnurus were preferred over other small mammals. The Awa Indians of north-western Ecuador and southern Colombia have been observed to trap echimyid rodents, especially Proechimys and Hoplomys, on a cyclical basis in order to manage these protein resources (Orejuela, 1992). In addition, Carrion de Samudio (1992) found that $P$. semispinosus was used for food by different ethnic groups in Panama.

It is not surprising that Afroecuadorian and Chachi families harvest small mammals. According to Redford and Robinson (1987), mammals accounted for the most important game taken by Neotropical indigenous and colonist groups, and rodents were frequently taken by both groups. Their analysis for rodents included squirrels and larger rodents (paca, agoutis and acouchis) and did not distinguish among 'other rodents', which had significantly lower average harvest rates than the larger rodents. In addition, small-bodied Neotropical mammals are usually more common than larger mammals (Robinson and Redford, 1986).

What is surprising is the level of effort and finesse that these ethnic groups dedicated to hunting small mammals. Many of the large game species of this region have been locally extirpated by over-hunting (Albuja and Mena,
1987; Pearson, 1992; Suárez, 1993) and this has placed a premium on the use of smaller mammals and riverine resources. This pattern has been observed for other villages where settlements tend to remain in one place for extended periods of time (Smith, 1976; Ayres and Ayres, 1979) and where rodent hunting was more significant in older settlements than in younger ones.

Afroecuadorian and Chachi hunters constructed their traps around family gardens and along forest trails. Setting traps around family gardens had the dual purpose of providing a protein source for the family while at the same time relieving predatory pressure on their gardens. In addition, gardens are tended daily and trap lines can be set and checked during visits to and from the family gardens. In this system of garden hunting (Linares, 1976), animal protein and carbohydrates are spatially concentrated and their abundance can be regulated.

Both Afroecuadorian and Chachi families set their traps for the same period of time - an average of 6 days - before closing them for another opportunity. Both groups left traps open until trapping success dropped significantly and effort outweighed success.

Interviews with Afroecuadorian families revealed that in the past individual families employed 100-200 traps daily. Today fewer traps are constructed and fewer animals captured; trapping small mammals represents a great deal of effort for little gain and local people are becoming dependent on purchased food. Afroecuadorian families set large numbers of traps only on special occasions, such as Easter week, patron saint holidays and Christmas. During one such holiday period observed during the study, 10 individuals from Playa de Oro each set 36-150 traps, representing a total of 475 traps. Trapping for the 3-day period before the holiday yielded 224 animals, 119 (53 per cent) of them being $P$. semispinosus. One hunter's trap line of 150 traps yielded 70 captures, 58 (83 per cent) of which were Proechimys.

It is clear that some of the lowland northwestern Andes ethnic groups have hunted Proechimys as a principal meat-providing small mammal. Proechimys spp. are the most 
widespread taxa of the family Echimyidae in the Neotropics (Hershkovitz, 1969), commonly appear on small mammal inventory lists, and have high densities (Arita et al., 1990). Emmons (1990) stated that Proechimys is one of the most abundant rodent genera found in lowland tropical forests, having 2-3 offspring as often as three to four times a year.

Arita et al. (1990) suggested that widespread and locally abundant Neotropical small mammal species probably do not require special conservation and management policies, except for those species that require high densities for successful breeding. In the case of Proechimys, Stallings (1989) did not record one capture of this genus in over 30,000 trap nights from a large conservation unit in south-eastern Brazil, where small mammal hunting was not allowed. This suggests that Proechimys could be locally extirpated by natural predators or by natural disasters, even if suitable habitat is available. In places where it is hunted, overharvesting could result in a significant reduction in numbers, drastically affecting the diets of ethnic groups that depend on this important protein source.

\section{Acknowledgments}

We would like to express our thanks to those community members who participated in this study and to INEFAN for granting us permission to carry out the study. This study was designed, financed and carried out through the SUBIR Project (Sustainable Uses of Biological Resources), an Agency for International Development funded Integrated Conservation and Development Project. Support for L. Suárez was also provided by the Tropical Conservation and Development Program at the University of Florida and the Wildlife Conservation Society.

\section{References}

Albuja, L. and Mena, P. 1987. Distribución y notas ecológicas de Proechimys semispinosus en el noroccidente Ecuatoriano. Politecnica: Revista de Información Técnico-Cientifica, Biologia, 12 (4), 145-160.

Arita, H.T., Robinson, J.G. and Redford, K.H. 1990. Rarity in neotropical forest mammals and its ecological correlates. Conservation Biology, 4 (2), 181-192.
Ayres, J.M. and Ayres, C. 1979. Aspectos da caca no alto Rio Aripuna. Acta Amazonica, 9, 287-298.

Cañadas, L. 1983. El mapa bioclimática y ecológica del Ecuador. MAG-PRONAREG. Quito, Ecuador.

Carrion de Samudio, J. 1992. Local People, Wildlife Use and a National Park in Bocas del Toro Archipelago, Panama. MA thesis, University of Florida, Gainesville.

Cevallos, J. 1993. Diversidad y abundancia relativa de mamíferos en dos zonas de la parte baja de la Reserva Ecologica Cotacachi-Cayapas. SUBIR biodiversity report, EcoCiencia, Quito.

Dallmeier, F. 1991. Whistling ducks as a manageable and sustainable resource in Venezuela: balancing economic costs and benefits. In Neotropical Wildife Use and Conservation (eds J. G. Robinson and K. H. Redford), pp. 266-287. University of Chicago Press, Chicago.

Emmons, L. H. 1990. Neotropical Rainforest Mammals. Chicago University Press, Chicago. 281 pp.

Hershkovitz, P. 1969. The evolution of mammals on southern continents. VI. The recent mammals of the neotropical region: zoogeographic and ecological review. Quar.Rev. Bio. 44 (1), 1-70.

Linares, O.F. 1976. Garden hunting in the American tropics. Human Ecology, 4, 331-349.

Mittermeier, R.A. 1991. Hunting and its effect on wild primate populations in Suriname. In Neotropical Wildlife Use and Conservation (eds J. G. Robinson and K. H. Redford), pp. 93-110. University of Chicago Press, Chicago.

Orejuela, J.E. 1992. Traditional productive systems of the Awa (Cuaiquer) Indians of Southwestern Colombia and neighboring Ecuador. In Conservation of Neotropical Forests: Working from Traditional Resource Use (eds K. H. Redford and C. Padoch), pp. 58-82. Columbia University Press, New York.

Pearson, D. 1992. Diagnostic Report on Wildlife in the Lower Portion of the Cotacachi-Cayapas Ecological Reserve. SUBIR Diagnostic Report, CARE/ Ecuador, Quito.

Purdy, P.C. and Tomlinson, R.E. 1991. The eastern white-winged dove: factors influencing use and continuity of the resource. In Neotropical Wildlife Use and Conservation (eds. J. G. Robinson and K. H. Redford), pp. 255-286. University of Chicago Press, Chicago.

Redford, K.H and Robinson, J.G. 1987. The game of choice: patterns of Indian and colonist hunting in the Neotropics. Am. Anthropol. 89, 650-657.

Robinson, J.G. and Redford, K.H. 1986. Body size, diet and population density of Neotropical forest mammals. Am. Nat. 128, 665-680.

Smith, N.G.H. 1976. Utilization of game along Brazil's Transamazon highway. Acta Amazonica, 6, 455-466. 
Stallings, J.R. 1989. Small mammal inventories in an eastern Brazilian park. Bull. Florida State Mus., Biol. Sci. 34 (4), 153-200.

Suárez, E. 1993. La importancia de los roedores y los marsupiales silvestres en la dieta de las comunidades Afroesmeraldeñas y Chachis de la zona baja del área de influencia de la Reserva Ecológia Cotacachi-Cayapas, Ecuador. SUBIR Technical Report, EcoCiencia, Quito.

Vickers, W.T. 1991. Hunting yields and game composition over ten years in an Amazon indian territory. In Neotropical Wildlife Use and Conservation (eds J. G. Robinson and K. H. Redford), pp. 53-81. University of Chicago Press, Chicago.

Esteban Suárez, EcoCiencia, Fundación Ecuatoriana de Estudios Ecológicos, PO Box 17-12-257, Tamayo 1339 y Av., Colón, Quito, Ecuador.

Jody R. Stallings, CARE/Ecuador, 151 Ellis Street, Atlanta, GA 30303, USA.

Luis Suárez, EcoCiencia, Fundación Ecuatoriana de Estudios Ecológicos, PO Box 17-12-257, Tamayo 1339 y Av., Colón, Quito, Ecuador. 